\title{
Stereoselective interaction of procyclidine, hexahydro-difenidol, hexbutinol and oxyphencyclimine, and of related antagonists, with four muscarinic receptors
}

\author{
Magali Waelbroeck ", Jean Camus ", Michèle Tastenoy ", Ernst Mutschler ", Carsten Strohmann ", \\ Reinhoid Tacke ", Lise Schjelderup ", Arne Aasen ", Günter Lambrecht ' and Jean Christophe " \\ "Deparment of Biochemistn and Nutrition, Mcdical School, Frec Unit crsity of Brussels, B-1070 Brussels, Belgium, "Depurtment of Pharmacelest: \\ Unitersity of Frankfurr. D-6000 Frankfurt am Main. Germamy. "Institule of Inorganic Chemistn. Unicersity of Karlsruhe, D-7500 Karlsruhe. \\ Germany, and "Depurtment of Pharmacy. Linirersity of Os/o. N-0316 Oslo.3, Nonsay.
}

Received 7 April 1992, accepted 28 April 1992

We investigated the binding properties of the (R)- and (S)-enantiomers of the muscarinic antagonists trihexyphenidyl, procyclidine, hexahydro-difenidol, p-fluoro-hexahydro-difenidol, hexbutinol, p-fluoro-hexbutinol, and their corresponding methiodides at muscarinic $M_{1}, M_{2}, M_{3}$ and $M_{4}$ receptor subtypes. In addition, binding properties of the (R)- and (S)-enantiomers of oxyphencyclimine were studied. The (R)- cnantiomers (cutomers) of all the compounds had a greater affinity than the (S)-isomers for the four muscarinic receptor subtypes. The binding patterns of the (R)- and (S)-enantiomers were generally different. We did not observe any general correlation between the potency of the high-affinity enantiomer and the affinity ratio (cudismic ratio) of the two cnantiomers. The results are discussed in terms of a 'four subsitcs' binding model.

Muscarinic receptors; Hexahydro-difenidol; Hexbutinol; Oxyphencyclimine: Eudismic analysis; Pfeiffer's rule; Stercoselectivity: Receptor interaction

\section{Introduction}

At least four muscarinic receptors can now be discriminated in radioligand experiments (Lazareno and Roberts, 1989; Michel et al., 1989; Lazareno et al., 1990; Waelbroeck et al., 1990a) and in pharmacological studies (Dörje et al., 1990), using a battery of selective antagonists. The $M_{1}$ receptors have the highest affinity for pirenzepine (Hammer et al., 1980), the $M_{2}$ receptors, the highest affinity for AF-DX 116 (Giachelli et al., 1986) and the $M_{3}$ and $M_{4}$ receptors have higher affinities than $M_{2}$ receptors for 4-diphenylacetoxy $N$ methyl piperidine methiodide (4-DAMP) (Barlow et al., 1976) and for hexahydro-sila-difenidol (Mutschler and Lambrecht, 1984; Lambrecht et al., 1989). The cardioselective drugs himbacine (Gilani and Cobbing, 1986) and methoctramine (Melchiorre et al., 1987) can be used to discriminate them from each other, because they have a higher affinity for $M_{4}$ than $M_{3}$ receptors.

Correspondence 10: J. Christuphe. Department of Biechemistry and Nutrition. Medical School. Free University of Brussels, Building G/E, CP 611, Rnute de Lennik 808. B-1070 Brussels. Belgium. Tel. 32-2-555.6228; Fix 32-2-55.5.62.30
The tissue distribution and antagonist binding properties of the $M_{1}, M_{2}, M_{3}$ and $M_{4}$ receptors are comparable to the tissue distribution of the $\mathrm{m} 1, \mathrm{~m} 2, \mathrm{~m} 3$ and $\mathrm{m} 4$ messenger RNAs and to the binding propertics of the corresponding cloned receptors expressed in different cell lines (Bonner, 1989; Levine and Birdsall, 1989; Dörje et al., 1991).

In the last few years, data have been accumulated suggesting that the muscarinic receptor subtypes can also be differentiated on the basis of their stereuselectivity (sce below). A special vocabulary was introduced to describe these data (Lehmann, 1986). The enantiomer with the higher affinity for the receptors is called the 'eutomer', the less affinitive, the 'distomer'. Their affinity ratio ('cudismic ratio') is a measure of the receptor's stercosclectivity. Its logarithm, the 'eudismic index', is proportional to the difference between the binding free chergies of the eutomer and distomer. The cudismic index of chiral muscarinic antagonists, such as procyclidine (Lambrecht and Mutschler, 1986; Tacke et al., 1986; Waelbroeck et al., 1990b), trihcxyphenidyl and its methiodide (Lambrecht et al., 1988), biperiden (Eltze and Figala, 1988), hexahydro-cifenidol and hexbutinol (Fcifel $c t$ al., 1990) as 
well as telenzepine (Eveleigh ot al., 1989) has been used as an additional criter : $\lrcorner. n$ for receptor classification. In the case of muscarinic antagonists carrying a 1,3-oxathiolane nucleus, there was also a clear-cut difference between the eudismic affinity quotient (which measures the variation of the eudismic index with cutomer affinity) when comparing the muscarinic receptors in the heart, biadder or iieum (Gualtieri ci al., 1990), supporting the hypothesis liat these receptors are different.

We compared in this work the aftınity and stercoselectivity of the enantiomers of several iertiary and quaternary chiral antagonists (see fig. I), all possessing a hydroxy, phenyl, and cyclohexyl group bound to the centre of chirality, but differing in the structure of the basic amino (ammonium) group and the structure of the chain connecting the carbinol carbon atom and the cationic head (fig. 1). In addition. four analogues with a para-fluoro-phenyl rather than phenyl group (fig. 1) were investigated. Affinity data were obtained in competition experiments using $\left[{ }^{3} \mathrm{H}\right] \mathrm{N}$-methyl scopolamine as radioligand. The receptors studied were the NB-OK 1 neuroblastoma $\left(M_{1}\right)$, rat cardiac $\left(M_{2}\right)$, and pancreas $\left(\mathrm{S}_{3}\right.$ ) receptors, and the rat striatum receptors with $\mathrm{M}_{4}$ binding properties. Our goals were 2-fold: (a) test the hypothesis that the receptor's stereoselectivity or eudismic affinity quotient can be used in combination with affinity values for receptor classification; (b) obtain a better understanding of the basis of enantiomer discrimination by muscarinic receptors (binding model).

The functional properties of the enantiomers of trihcxyphenidyl (compound 1 in fig. 1) and its methiodide (2) (Lambresia at al., 1988), procyclidine (3) and tricyclamol (4) (Tacke et al., 1986), hexahydro-difenidol (5) as well as hexbutinol (9), its methiodide (10) and p-fluoro-hexbutinui (ii) (Frif́ci ci di., 1990) tô muscarinic receptor subtypes have been reported elsewhere. The binding aftinities of the enantiomers of compounds 3 and 5-8 at muscarinic receptor subtypes have also been described (Waelbroeck et al., 1990b, 1991a,b).

\section{Materials and methods}

\subsection{Cell and tissue preparations}

Human NB-OK 1 neuroblastoma cells (a generous gift from Dr. Yanaihara, Shizuoka, Japan) were maintained in RPMI 1640 medium, enriched with $100 \mathrm{U} / \mathrm{ml}$<smiles>OC(CCN1CCCC1)(c1ccccc1)c1ccccc1</smiles>

1<smiles>CN1CCN1CCC(O)(c1ccccc1)C1CCCCC1</smiles>

$\therefore$<smiles></smiles>

?<smiles>CN1CCCN1CC#CC(O)(c1ccccc1)c1ccccc1</smiles>

10<smiles>CN1CCCN1CCC(O)(c1ccccc1)c1ccccc1</smiles>

2<smiles>OC(CCCCN1CCCC1)(c1ccccc1)c1ccccc1</smiles>

$\underline{5}$<smiles>CN1CCC[N+]1(C)CCCCC(O)(c1ccccc1)c1ccc(F)cc1</smiles>
B<smiles>OC(C#CCN1CCCC1)(c1ccc(F)cc1)C1CCCCC1</smiles>

II<smiles>CN1CCN=C1COC(=O)C(O)(c1ccccc1)c1ccccc1</smiles>

13<smiles>OC(CCN1CCC1)(c1ccccc1)c1ccccc1</smiles>

3<smiles>CN1CCCN1CCCCC(O)(c1ccccc1)C1CCCCC1</smiles>

6<smiles>OC(C#CCN1CCCC1)(c1ccccc1)C1CCCCC1</smiles>

g<smiles>C[N+]1(CC#CC(O)(c2ccccc2)C2CCCC2)CCCC1</smiles>

12

Fig. 1. Chemical structure of the compounds $(1-13)$ investigated in this study. 
penicillin, $100 \mu \mathrm{g} / \mathrm{ml}$ streptomycin and $10 \%$ foetal calf serum (from Gibco, Gent, Belgium). Twice a week the cells were detached by trypsin-EDTA (Gibco. Gent. Belgium) and divided $1 / 3$. For $\left[{ }^{3} \mathrm{H}\right] \mathrm{N}$-methyl scopolamine ([ $\left.{ }^{3} \mathrm{H}\right]$ NMS) binding experiments, the cells were harvested using a $20 \mathrm{mM}$ sodium phosphate buffer enriched with $1 \mathrm{mM}$ EDTA and $150 \mathrm{mM} \mathrm{NaCl}(\mathrm{pH}$ 7.4), centrifuged at $500 \times g$ for $5 \mathrm{~min}$, resuspended and homogenized in $20 \mathrm{mM}$ Tris- $\mathrm{HCl}$ buffer enriched with $5 \mathrm{mM} \mathrm{MgCl} 2(\mathrm{pH} 7.5)$ in a glass-Teflon homogenizer, and then stored in liguid nitrngen until use.

For cardiac homogenates male Wistar albino rats (200-250 g) were killed by decapitation, and the heart was immediately removed and rinsed in $150 \mathrm{mM} \mathrm{NaCl}$. The homogenization buffer contained $20 \mathrm{mM}$ Tris- $\mathrm{HCl}$ (pH 7.5) and $250 \mathrm{mM}$ sucrose. Each heart was homogenized in $2 \mathrm{ml}$ of this buffer with : n Ultraturrax homogenizer (maximal speed for $5: 4^{\circ} \mathrm{C}$ ) followed by further addition of $13 \mathrm{ml}$ of buffer, and 7 up and down strokes in a glass-Teflon homogenizer (at $4^{\circ} \mathrm{C}$ ). The homogenate was filtered on two layers of medical gauze and either used immediately or stored in liquid nitrogen until use.

For rat striatum homogenates the brain was immediately removed and dissected. The striatum was homogenized in $2 \mathrm{ml}$ of $20 \mathrm{mM}$ Tris- $\mathrm{HCl}$ buffer ( $\mathrm{pH} 7.5$ ) enriched with $250 \mathrm{mM}$ sucrose, with a glass-Teflon homogenizer, and stored in liquid nitrogen until use. These homogenates were diluted 20-fold with the homogenization buffer before use for $\left[{ }^{3} \mathrm{H}\right] \mathrm{NMS}$ binding experiments.

For rat pancreas homogenates the organ was immediately removed, minced with s.issors and homogenized in a glass-Teflon homogenizer ( 7 up and down strokes at $4^{\circ} \mathrm{C}$ ) in a solution containing $300 \mathrm{mM}$ sucrose, $0.2 \mathrm{mg} / \mathrm{ml}$ bacitracin and 500 kallikrcin inhibitor $\mathrm{U} / \mathrm{ml}$ of Trasylol (Bayer, Brussels, Belgium). The resulting homogenate was immediately filtered on two layers of medical gauze and diluted 11 -fold with the incubation buffer.

\section{2. $I^{3} \mathrm{H} / N M S$ binding experiments}

$\left[{ }^{3} \mathrm{H}\right.$ ]NMS binding was measured at $25^{\circ} \mathrm{C}$ in a total volume of $1.2 \mathrm{ml}$ using the following incubation buffer: $50 \mathrm{mM}$ sodium phosphate (pH 7.4) enriched with 2 $\mathrm{mM} \mathrm{MgCl}, 1 \%$ bovine serum albumin (except when indicated) and the indicated tracer and drug concentrations. Addition of bovine serum albunin to the incubation buffer increased $\left[{ }^{3} \mathrm{H}\right] \mathrm{NMS}$ binding very slightly (by at most $10-15 \%$ ) and improved the reproducibility of duplicates in our filtration assays. In binding experiments on pancreas homogenates, we also added Trasylol and bacitracin (see above) to further inhibit proteolytic activity. Bovine serum albumin was an essential ingredient in pancreas binding studies, since the binding capacity of pancreas homogenates disappeared within $40 \mathrm{~min}$ at room temperature if this protein was omitted from the buffer. but was maintained over $90 \%$ for at least $4 \mathrm{~h}$ in its presence.

To terminate the incubation, each satmple was diluted with $2 \mathrm{ml}$ of ice-cold $50 \mathrm{mM}$ sodium phosphate buffer ( $\mathrm{pH} 7.4)$ and filtered on GF/C glass-fi re filters (Whatman. Maidstone. UK) presoated in $0.155^{\prime}$; polyethylenimine. The filters were rinsed 3 times with the same filtration buffer, dried. and the radioactivity (bound tracer) counted by liquid scintillation. Nonspecific binding was defined as ['H]NMS binding in the presence of $1 \mu \mathrm{M}$ atropine.

For $\left[{ }^{3} \mathrm{H}\right]$ NMS binding to human NB-OK 1 cell homogenates, a $0.25 \mathrm{nM}$ tracer concentration (2-fold $K_{1}$ ) for $M_{1}$ receptors) was chosen with a homogenate concentration of $160-200 \mu \mathrm{g}$ protein per assay (about 50 pM binding sites) and an incubation period of $2 \mathrm{~h}$ at $25^{\circ} \mathrm{C}$ allowing full equilibration of tracer binding.

In binding experiments on rat cardiac homogenates. a $1 \mathrm{nM}\left[{ }^{3} \mathrm{H}\right] \mathrm{NMS}$ concentration $\left(2\right.$-fold $K_{1}$ ) at $\mathrm{M}_{2}$ receptors) was selected with a homogenate concentration of $400-500 \mu \mathrm{g}$ protein per assay (about $250 \mathrm{pM}$ binding sites) and a $2 \mathrm{~h}$ incubation period at $25^{\circ} \mathrm{C}$ allowing full equilibration of tracer binding.

In binding experiments on rat striatum homogenates, the tracer concentration was $0.25 \mathrm{nM}$ and the protein concentration 30-40 $\mu \mathrm{g}$ per assay (about $50 \mathrm{pM}$ binding sites). Under equilibrium conditions ( 2 $h$ incubation at $\left.25^{\circ} \mathrm{C}\right)\left[{ }^{3} \mathrm{H}\right] \mathrm{NMS}$ labelled $\mathrm{M}_{1}, \mathrm{M}_{3}$ and $M_{4}$ sites in this brain region. To analyze tracer binding to $M_{4}$ sites only, we preincubated striatum homogenates for $2 \mathrm{~h}$ at $25^{\circ} \mathrm{C}$ to allow equilibrium binding, then induced tracer dissociation by adding $\mathrm{I} \mu \mathrm{M}$ atropine. [ $\left.{ }^{3} \mathrm{H}\right] \mathrm{NMS}$ dissociated from its binding sites after $35 \mathrm{~min}$ of isotopic dilution, the residual binding being about $30 \%$ of initial binding. Since [ $\left.{ }^{3} \mathrm{H}\right] \mathrm{NMS}$ dissociation from $M_{1}$ sites is faster than that from $M_{3}$ and $\mathrm{M}_{4}$ sites, $85 \%$ of this residual [ ${ }^{3} \mathrm{H}$ ]NMS hinding corresponded to $M_{+}$binding sites (Waelbroeck et al.. 199()a).

It is necessary to keep tracer binding below $15 \%$ of the total tracer added to avoid distortions of the competition curves due to tracer or unlabelled drug depletion. This means that the residual tracer binding to striatum $M_{4}\left(+M_{3}\right)$ sites in the absence of unlabelled drug must be maintained below $5 \%$ of the total tracer added (i.c. $30 \%$ of the $15 \%$ initial binding). We therefore decided to use a comparatively high [ $\left.{ }^{3} \mathrm{H}\right] \mathrm{NMS}$ concentration $\left(0.25 \mathrm{nM}\right.$, equivalent to 5 -fold $\left.\mathrm{K}_{1}\right)$ at $\mathrm{M}_{4}$ sites) for these experiments.

In binding experiments on rat pancreas homogenates we used $980 \mu \mathrm{l}$ of the homogenate per 1.2 $\mathrm{ml}$ sample. The $\left[{ }^{3} \mathrm{H}\right] \mathrm{NMS}$ concentration was $0.25 \mathrm{nM}$ (2-fold $\mathrm{K}_{\mathrm{D}}$ at $\mathrm{M}_{3}$ receptors) and protein concentration $800-1000 \mu \mathrm{g}$ per assay (2bout $50 \mathrm{pM}$ binding sites). An 
incubation period of $4 \mathrm{~h}$ was necessary to allow binding equilibrium.

Protein concentration was measured according to Lowry et al. (1951) using bovine serum albumin as standard.

\subsection{Data analysis and statistics}

The competition curves for unlabelled antagonists $1-i 3$ (fig. 1) were analyzed using the computer program described by Richardson and Humrich (1984), and were compatible with the existence of a single receptor subtype. $\mathrm{K}_{\mathrm{i}}$ values were calculated from $\mathrm{IC}_{501}$ values using the Cheng and Prusoff (1973) equation. The $\mathrm{pK}_{\mathrm{i}}$ values, presented in table 1 and figs. 2 and 3 as means, were defined as $-\log \mathrm{K}_{\mathrm{i}}$. Each experiment was repeated at least 3 times. The standard deviation of each IC $_{51}$ value was below $30 \%$ of the average value in all cases (corresponding to $\mathrm{pK}_{\mathrm{i}}$ standard deviations of $<0.1 \log$ unit) and was therefore not mentioned in table 1 and figs. 2 and 3 .

\subsection{Drugs and chemicals}

$\left[{ }^{3} \mathrm{H}\right] \mathrm{N}$-methyl-scopolamine ([ $\left.\left.{ }^{3} \mathrm{H}\right] \mathrm{NMS}, 74 \mathrm{Ci} / \mathrm{mmol}\right)$ was obtained from Amersham International (Bucks., UK). Atrupine, polyethylenimine and bovine scrum albumin (Cohn fraction V) were obtained from Sigma Chemical Co. (St. Louis, MO, USA). Tissue culture material and media were obtained from Gibco (Gent, Belgium). All other chemicals were of the highest grade available.

The (R)- and (S)-enantiomers of trihexyphenidyl ((R)-1 and (S)-1; as hydrochlorides) (Schjelderup at al., 1987) and trihexyphenidyl methiodide ((R)-2 and (S)-2) (Schjelderup et al., 1987 and unpublished results), procyclidine ((R)-3 and (S)-3) (Tacke et al., 1986), tricy- clamol iodide ((R)-4 and (S)-4) (Tacke ct al., 1986), hexahydro-difenidol ((R)-5 and (S)-5; as hydrochlorides) (Tacke et al., 1989), p-fluoro-hexahydro-difenidol) ((R)-7 and (S)-7 as hydrochlorides) (Strohmann et al., 1991), p-fluoro-hexahydro-difenidol methiodide ((R)-8 and (S)-8) (Strohmann et al., 1991), hexbutinol ((R)-9 and (S)-9) (Tacke et al., 1989), hexbutinol methiodide ((R)-10 and (S)-10) (Feifel et al., 1990), and p-fluoro-hexbutinol ((R)-11 and (S)-11) (Strohmann et al, 1991) and oxyphencylimine ( $R ;-; 3$ and $(S)-1,2$, as hydrochlorides) (Schjelderup et al., 1988) were synthesized according to the literature. The (S)-enantiomer of p-fluoro-hexbutinol methiodide ((R)-12 and (S)-12) was also synthesized according to the literature (Strohmann et al., 1991; in this paper, the sign of the optical rotation of (S)-12 is wrong; (S)-12 is not the laeverotatory, but the dextrorotatory enantiomer).

The enantiomers of hexahydro-difenidol methiodide ((R)-6 and (S)-6) were prepared by quaternization of (R)-5 and (S)-5, respectively, with methyl iodide in acctone, following the procedure described for the synthesis of (R)-8 and (S)-8 (sec Strohmann et al., 1991).

(R)-6: $\mathrm{C}_{22} \mathrm{H}_{36}$ INO (457.4), yield 84\%, m.p. 138$139^{\circ} \mathrm{C}$ (acctonc/dictiyl cther, colourless needles), $[\alpha]_{5 \times,}^{27}=-14\left(\mathrm{c}=0.5, \mathrm{CHCl}_{3}\right)$, ce $>99.7 \%$. Found: $\mathrm{C}$, 57.4: H, 8.3; N, 3.(). Calculated: C, 57.77; H, 7.93; N, 3.06. Structural characterization by ${ }^{1} \mathrm{H}$ and ${ }^{1.3} \mathrm{C}$ NMR spectroscopic sludies (data not given).

(S)-6: $\mathrm{C}_{22} \mathrm{H}_{36}$ INO (457.4), yield $88 \%$, m.p. 138$139^{\circ} \mathrm{C}$ (acctone/diethyl ether, colourless needles), $[\alpha]_{S_{K h}}^{27}=14\left(\mathrm{c}=0.5, \mathrm{CHCl}_{3}\right)$, ee $>99.7 \%$. Found: $\mathrm{C}$, 57.4; H, 8.3; N, 3.0. Calculated: C, 57.77; H. 7.93; N, 3.06. Structural characterization by ${ }^{1} \mathrm{H}$ and ${ }^{1.3} \mathrm{C}$ NMR spectroscopic studies (data not given).

The (R)-enantiomer of $p$-fluoro-hexbutinol methiodide ((R)-12) was prepared by quaternization of (R)-11

TABLE: 1

pK, values of the (R)- and (S)-enantiomers of the muscarinic antagonists $1-13$ for four muscarinic receptor subtypes.

\begin{tabular}{|c|c|c|c|c|}
\hline $\begin{array}{l}\text { Muscarinic antagonist } \\
\text { No. (name) }\end{array}$ & $\begin{array}{l}M_{1}(N B-O K \text { I) } \\
(R) /(S)\end{array}$ & $\begin{array}{l}M_{2} \text { (hcirl) } \\
\text { (Ri/(S) }\end{array}$ & $\begin{array}{l}M_{3} \text { (pancreas) } \\
(R) /(S)\end{array}$ & $\begin{array}{l}M_{+} \text {(in strialum) } \\
(R) /(S)\end{array}$ \\
\hline I (trihexyphenidyl) & $8.9 / 0.5$ & $7.7 / 6.1$ & $8.1 / 5.5$ & $8.8 / 6.3$ \\
\hline 2 (trihexyphenidyl methiodide) & $9.6 / 7.4$ & $8.6 / 6.9$ & $8.6 / 6.4$ & $9.2 / 7.11$ \\
\hline 3 (procyclidine) & $8.4 / 6.2$ & $7.3 / 5.84$ & $7.8 / 5.5$ & $8.1 / 6.0$ \\
\hline 4 (Iricyclamol indide) & $9.4 / 6.9$ & $8.3 / 6.6$ & $8.0 / 5.9$ & $8.9 / 6.5$ \\
\hline 5 (hexahydro-difenidol) $"$ & $8.2 / 6.1$ & $7.11 / 5.8$ & $8.1 / 5.9$ & $7.9 / 6.11$ \\
\hline 6 (hexahydro-difenidol methiodide) & $8.6 / 6.5$ & $8.2 / 6.0$ & $8.1 / 5.5$ & $8.4 / 6.1$ \\
\hline 7 (p-lluoro-hexahydro-difenidol) & $7.9 / 5.9^{h}$ & $0.7 / 5.6^{\prime \prime}$ & $7.9 / 5.8$ & $7.9 / 5.8^{\prime \prime}$ \\
\hline$R$ (p-fluoro-hexahydro-difenidol methiodide) & $8.4 / 6.3^{\circ}$ & $7.8 / 5.9^{\mathrm{b}}$ & $8.2 / 6.2$ & $8.2 / 6.2^{\prime \prime}$ \\
\hline 9 (hexbulinol) & $8.4 / 7.3$ & $8.0 / 7.0$ & - & $9.3 / 8.2$ \\
\hline 10 (hexbutinol methiodide & $8.8 / 76$ & $8.3 / 7.4$ & - & $9.0 / 7.8$ \\
\hline 11 (p-fluoro-hexbutinul) & $8.2 ハ .10$ & $7.3 / 7.1$ & - & $8.4 / 8.3$ \\
\hline 12 (p-fluoro-hexbutinol methiodicic) & $\cdot . .3 / 8.0$ & $7.8 / 7.5$ & - & $8.4 / 7.8$ \\
\hline 13 (oxyphencyclimine) & 9.017 .5 & $8.7 / 7.1$ & - & $9.2 / 7.5$ \\
\hline
\end{tabular}

"Data taken from Waelhroeck et al.. 199(b): "Jala taken from Waelbrock et al.. I9y)la. 
with methyl iodide in acetonc, following the procedure described for the synthesis of (S)-12 (see Strohmann et al., 1991). (R)-12: $\mathrm{C}_{22} \mathrm{H}_{31}$ FINO (471.4), yield $82 \%$, m.p. (dec.) $190^{\circ} \mathrm{C}$ (acetonc/diethyl ether, colourless needles), $[\alpha]_{5 K_{0}}^{27}=-2\left(\mathrm{c}=0.5, \mathrm{CHCl}_{3}\right)$, ee $>99.8 \%$. Found: C, 56.2; H, 6.5: N. 2.9. Culculated: C, 56.06; $\mathrm{H}_{\mathrm{C}}$ 6.63; N. 2.97. Structural characterization by ${ }^{\prime} \mathrm{H}$ and ${ }^{\mathrm{i}}{ }^{3} \mathrm{C}$ NMR spectroscopic studies (data not given).

\section{Results}

\subsection{General considerations}

All the competition curves obtained in this study were compatible with the existence of a single receptor subtype in the different preparations with Hill coefficients not significantly different from unity $\left(n_{11}\right.$ varied between 0.95 and 1.10, with standard deviations below or equal to 0.05 ). This suggested that $\left[{ }^{3} \mathrm{H}\right] \mathrm{NMS}$ labelled single binding sites in each tissue or cell type.

Competition curves with (R)- and (S)-hexbutinol, (R)- and (S)-9 and (R)- and (S)-10-11 and -12 analogues and oxyphencyclimine ((R)- and (S)-13) were shifted to the right by $0.5-1.0 \log$ units in all preparations in the presence of $1 \%$ bovine serum albumin (data not shown). We therefore determined the binding affinities of the enantiomers of compounds $9-13$ to muscarinic receptors in homogenates from human NBOK 1 cells, rat heart and striatum in the absence of bovine seruin albumin. $\mathrm{pK}_{\mathrm{i}}$ values are given in table 1.

The bincing properties of the (R)- and (S)-enantiomers of p-fiuoro-hexahydro-difenidol (7) and its methiodide (8) to rat pancreas receptors were previously estimated by comparison of competition curves in pancreas and brain cortex with $1 \%$ bovine serum albumin in the incubation buffer (see Materials and methods) and in cortex without bovine serum albumin (War.ibrock et al., 1991a).

\subsection{Receptor binding profiles of the $(R)$ - and $(S)$-enanti- omers}

As shown in table 1, the receptor binding profiles of the $(R)$ - and (S)-enantiomers of the chiral drugs $1-13$ were generally different. (R)-Trihexyphenidyl ((R)-1), (R)-tritexyphenidyl methiodide ((R)-2), (R)-procyclid.ne ((R)-3) and (R)-tricyclamol iodide ((R)-4i had a clear $M_{1}>M_{2}$ selectivity, high affinities for $M_{4}$ sites and intermediate or low affinities for the $\mathrm{M}_{3}$ sites. In contrast, their (S)-enantiomers had an $M_{1}>M_{3}$ selectivity, with intermediate affinities for the $M_{2}$ and $M_{4}$ sites. (R)-Hexahydro-difenidol ((R)-5) and (R)-p-fluoro-hexahydro-difenidol ((R)-7) had a preference for $M_{1}, M_{3}$ and $M_{4}$ over $M_{2}$ sites, while (S)-hexahydrodifenidol and (S)-p-fluoro-hexahydro-difenidol were non-selective. (R)-Hexahydro-difenidol methiodide ((R)-6) was almost non-selective, but (S)-hexahydro-difenidol methiodide $M_{1}>M_{3}$ preferring. (R)-Hexbutinol ((R)-9) was $M_{1}, M_{4}>M_{2}$ preferring, but (S)-hexbutinol ((S)-9) selective for $M_{4}$ over $M_{1}$ and $M_{2}$ sites. In contrast with these results, the (R)- and (S)-enantiomers of p-flucro-hexbutinoi (11) and p-fluorohexbutinol methiodide (12) had the same selectivity for $M_{1}, M_{4}>M_{2}$ sites. The (R)- and (S)-enantiomers of p-fluoro-hexahydro-difenidoi methiodide (8), hexbutinol methiodide (10) and oxyphencyclimine (13) were almost non-selective.

\subsection{Stereosel-ctility at muscarinic receptors}

The ( $R$ )-enantiomers (eutomers) of compounds $1-13$ displayed higher affinities for $M_{1}-M_{4}$ receptors than the (S)-isomers (distomers), the eudismic indexes vary-

TABLE 2

Eudismic indexes (differences between the $\mathrm{pK}_{i}$ values of the (R)- and (S)-enantiomers) of the antimuscarinics $1-13$ at four muscarinic receptor subtypes.

\begin{tabular}{|c|c|c|c|c|}
\hline Muscarinic antagonist & $\mathrm{M}_{1}(\mathrm{NB}-\mathrm{OK}$ l) & $M_{2}$ (heart) & $M_{3}$ (pancreas) & $\mathrm{M}_{4}$ (in strialum) \\
\hline 1 (trihexyphenidyl) & 2.4 & 1.6 & 2.6 & 2.5 \\
\hline 2 (Irihexyphenidyl methiodide) & 2.2 & 1.7 & 2.2 & 2.2 \\
\hline 3 (procyclidine) & 2.1 & 1.5 & 2.3 & 2.1 \\
\hline 4 (tricyclamol iodide) & 2.5 & 1.7 & 2.7 & 2.4 \\
\hline 5 (hexahydro-difenidol) & 2.1 & 1.2 & 2.2 & 1.9 \\
\hline 6 (hexahydro-difenidol methiodide) & 2.1 & 2.2 & 2.6 & 2.3 \\
\hline 7 (p-fluoro-hexahydro-difenidoi) & 2.0 & 1.1 & 2.1 & 2.1 \\
\hline 8 (p-nuoro hexahydro-difenidol methiodide) & 2.1 & 1.9 & 2.0 & 2.0 \\
\hline 9 (hexbutinol) & 1.6 & 1.0 & - & 1.1 \\
\hline 10 thexbutinol methiodide) & 1.2 & 0.9 & - & 1.2 \\
\hline 11 (p-fluoro-hexbutinol) & 0.2 & (1).2 & -. & 0.1 \\
\hline 12 (p-fluoro-hexbutinol methiodide) & 0.3 & $0 . .3$ & - & 0.6 \\
\hline 13 (oxyphencyclimine) & 1.5 & 1.6 & - & 1.7 \\
\hline
\end{tabular}




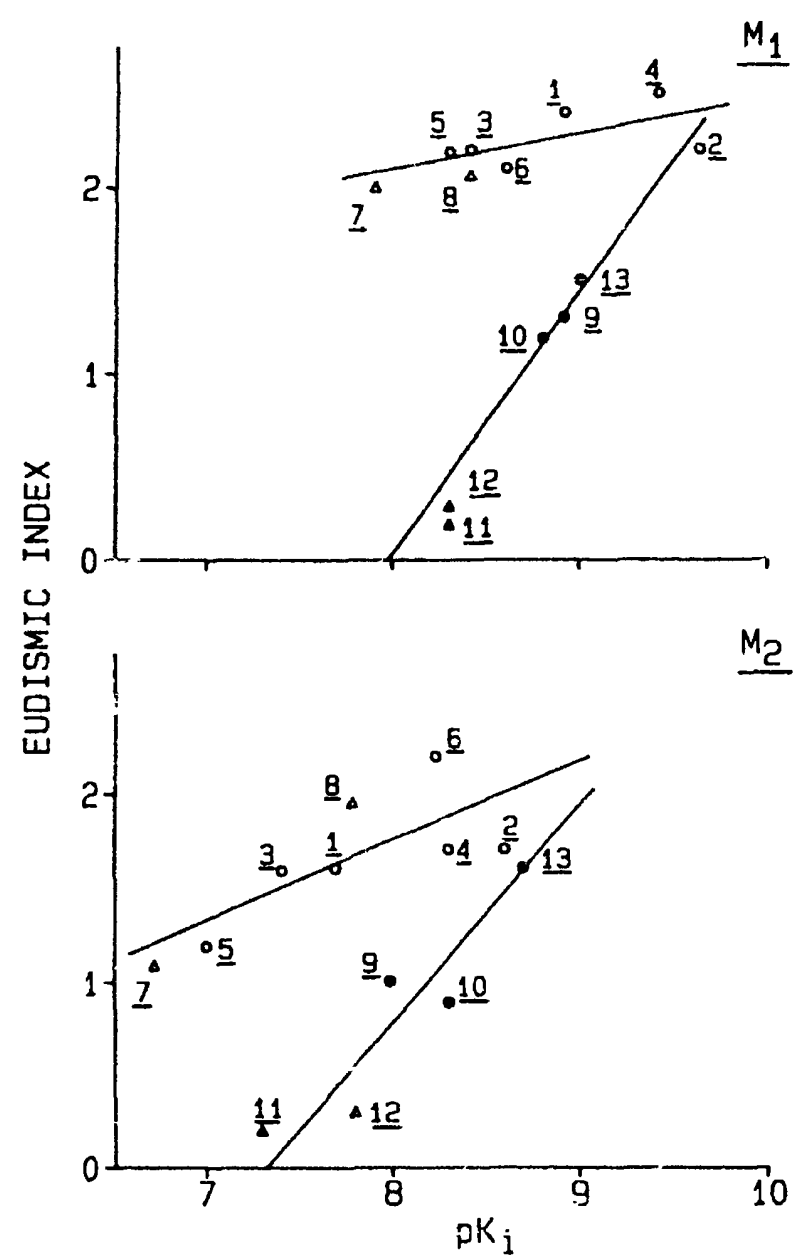

Fig. 2. The eudismic indexes of the phenyl compounds (1-6, 9. 10 and 13$)$ (circles) and the p-fluorophenyl derivatives $(7,8,11$ and 12) (triangles) were plotted as a function of the eutomer affinity. The numbers identify the compounds shown in fig. 1 and table 1 . and the correlation lines are described in table 3. Top panel: $M_{1}$ receptors; bottom panel: $M_{2}$ receptors.

ing by more than two orders of magnitude. These observed stereoselectivitie: did not appear to be associated in general with high aifinity of the eutomer (see below).

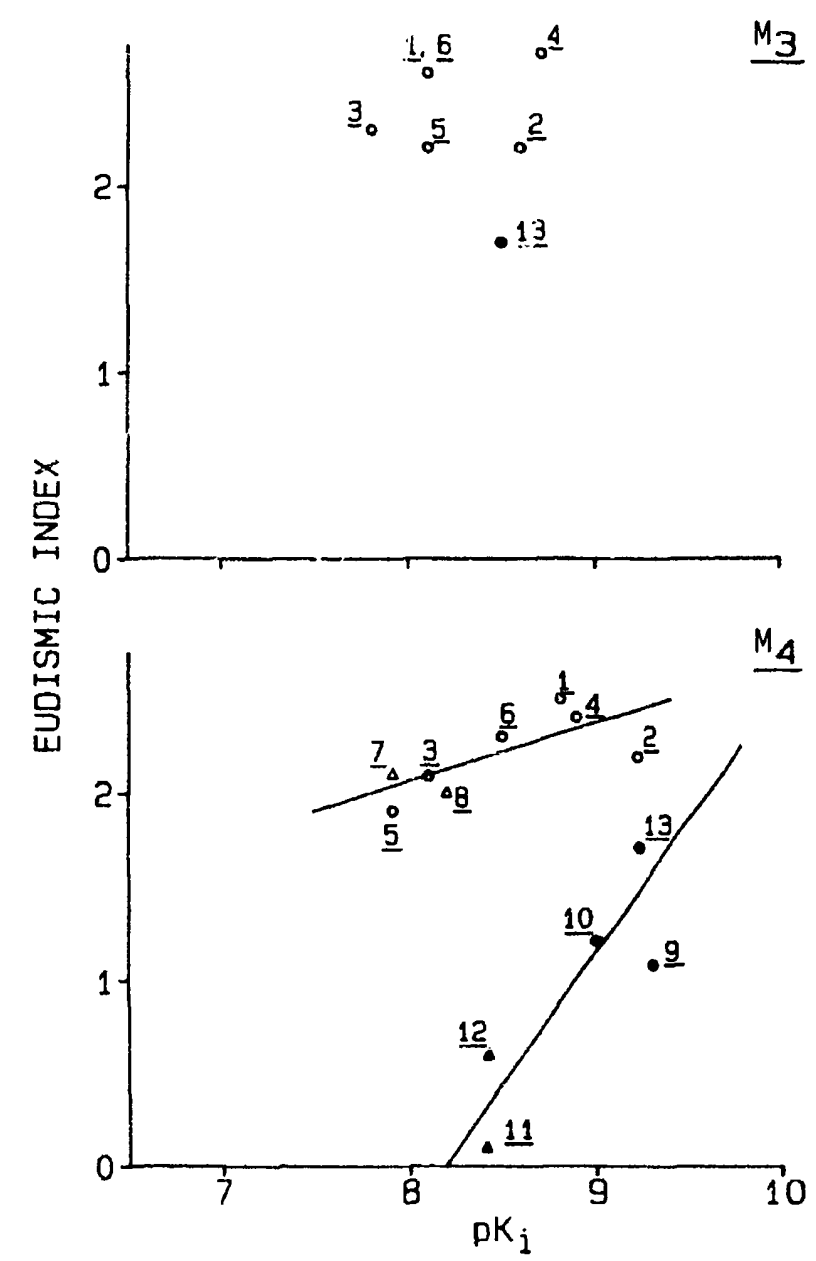

Fig. 3. As in fig. 2. Top panel: $M_{3}$ receptors; hotton panel: $M_{4}$ receptors.

As shown in table 2, the enantioselectivity ratios of compounds $1-5$ and 7 consistently showed the same order: $M_{1} \approx M_{3} \approx M_{4}>M_{2}$. This implies that the stereochemical demands made by the muscarinic receptor subtypes were different for the enantiomers of compounds $1-5$ and 7 , being least stringent at $\mathbf{M}_{2}$ receptors. In contrast, the eudismic indexes for the two

TABLE 3

The correlation lines shown in figs. 2 and 3 can be described as 'eudismic index $=a+b\left(p K_{1}\right)$ ' with the indicated values of ' $a$ ' and ' $b$ ' $a$. The correlation coefficient $r$, and the probability $(P)$ that the slope is different from zero are also indicated.

\begin{tabular}{|c|c|c|c|c|c|}
\hline $\begin{array}{l}\text { Receptor } \\
\text { subtype }\end{array}$ & $\begin{array}{l}\text { Compound } \\
\text { No. }\end{array}$ & $\mathbf{a}$ & b & $r$ & $\mathbf{P}$ \\
\hline $\begin{array}{l}\overline{M_{1}} \\
\mathbf{M}_{1}\end{array}$ & $\begin{aligned} 1 & \rightarrow 8 \\
2.4 .9 & \rightarrow 13\end{aligned}$ & $\begin{array}{r}0.56 \\
-13.17\end{array}$ & $\begin{array}{l}0.19 \pm 0.09 \\
1.63 \pm 0.13\end{array}$ & $\begin{array}{l}0.68 \\
0.98\end{array}$ & $\begin{array}{l}<0.10 \\
<0.02\end{array}$ \\
\hline $\begin{array}{l}M_{2} \\
M_{2}\end{array}$ & $\begin{aligned} 1 & \rightarrow 8 \\
2,9 & \rightarrow 13\end{aligned}$ & $\begin{array}{l}-1.61 \\
-8.06\end{array}$ & $\begin{array}{l}0.42 \pm 0.12 \\
1.11 \pm 0.26\end{array}$ & $\begin{array}{l}0.77 \\
0.95\end{array}$ & $\begin{array}{l}<0.05 \\
<0.05\end{array}$ \\
\hline$M_{3}$ & $1 \rightarrow 8$ & 0.46 & $0.23 \pm 0.32$ & 0.26 & n.s. ${ }^{n}$ \\
\hline $\begin{array}{l}M_{4} \\
M_{4}\end{array}$ & $\begin{aligned} 1 & \rightarrow 8 \\
2.9 & \rightarrow 13\end{aligned}$ & $\begin{array}{r}-0.34 \\
-12.14\end{array}$ & $\begin{array}{l}0.30 \pm 0.11 \\
1.49 \pm 0.59\end{array}$ & $\begin{array}{l}0.72 \\
0.82\end{array}$ & $\begin{array}{l}<0.05 \\
<0.10\end{array}$ \\
\hline
\end{tabular}

' $a$ ' is the eudismic index expected for a compound with a $\mathrm{pK}_{\mathrm{i}}=0\left(\mathrm{~K}_{\mathrm{i}}\right.$ 'alue $=1$ molar) and ' $\mathrm{b}$ ', sometimes called 'cudismic affinity quoticnt', measures the slope of the line (i.e. the variation of stereoselectivity with affinity). ${ }^{h} n . s .=$ not significant. 
methiodides 6 and 8 were very similar $(1.9-2.6)$ at the four receptor subtypes. This was mainly based on the fact that $\mathrm{N}$-methylation selectively increased the affinity of the (R)-enantiomers of the lertiary amines 5 and 7 at $M_{2}$ receptors by more than one order of magnitude.

The compounds 9-12 with a triple bond within the molecule had a lower eudismic index than the saturated drugs 1-8 (table 2) at all subtypes studied. The same held true for oxyphencyclimine at $M_{1}$ ano $M_{4}$ receptors.

\subsection{Correlation of the eutomer affinity and eudismic index}

We plotted in figs. 2 and 3 the eudismic index (difference between the $p K_{i}$ values of the $(R)$ - and (S)-enantiomers) as a function of the affinity $\left(\mathrm{pK}_{\mathrm{i}}\right.$ value) of the (R)-enantiomer (eutomer). We found no significant correlation between the affinity constants of either all the eutomers or of all the unsubstituted eutomers $(1-6,9,10,13)$ and their eudismic indexes, at any subtype. Thanks to the presence of compounds 11 and 12 in our set of data, we were able to subdivide the data into two groups (by visual inspection) for analysis. The eudismic index of compounds 1-8 table 1) did not vary significantly with the eutomer $\mathrm{pK}_{\mathrm{i}}$ value at $\mathrm{M}_{3}$ receptors, and increased slightly with the $\mathrm{pK}_{i}$ value at $M_{1}, M_{2}$ and $M_{4}$ receptors. In contrast, the eudismic index of compounds 4, 9-13 and (at $M_{1}$ receptors only) 2 varied at least as much as the $\mathrm{pK}_{\mathrm{i}}$ value of the eutomer, at $M_{1}, M_{2}$ and $M_{4}$ receptors. The statistical parameters describing the regression lines (figs. 2 and 3 ) are summarized in table 3.

\section{Discussion}

We investigater in this study the binding affinities of the enantiomers of oxyphencyclimine and of tertiary and quaternary compounds structurally related to hexahydro-difenidol and hexbutinol at muscarinic $M_{1}$ (NB-OK 1 cells), $M_{2}$ (rat heart), $M_{3}$ (rat pancreas) and $\mathrm{M}_{4}$ receptors (rat striatum). Our main goals were to test the hypothesis that eudismic analysis data may be used in receptor classification and to obtain more information about the enantiomer-discriminating properties of muscarinic receptor subtypes.

\subsection{Binding profile of the enantiomers and receptor classification}

The subtype selectivily of most of the enantiomers studied depended on their absolute configuration. The (R)-enantiomers of compounds $1-13$ had a greater affinity for $M_{1}-M_{4}$ ticeptors than the (S)-isomers (ta- bles 1 and 2). There was no rule governing the relative binding pattern of the (R)- and (S)-enantioners. For example: (R)-hexahydro-difenidol ((R)-5) and (R)-pfluoro-hexahydro-difenidol ((R)-7) had low affinitics for $M_{2}$ receptors (as compared to $M_{1}, M_{3}$ and $M_{4}$ receptors), but (S)-5 and (S)-7 were non-selective. In contrast, the two enantiomers of hexbutinol methiodide (10), p-fluoro-hexbutinol (11), p-fluoro-hexbutinol methiodide (12) and oxyphencyclimine (13) had qualitatively the same binding pattern, (R)- and (S)-(11) being $M_{1}, M_{4}>M_{2}$ selective.

Some of the enantiomer pairs studied are of special interest for receptor classification: for example. (R)-trihexyphenidyl methiodide ((R)-2) and (R)-tricyclamol ((R)-4) discriminated with the highest selectivity $M_{1}$ from $M_{2}$ receptors, but (S)-2 and (S)-4, $M_{1}$ from $M_{3}$ receptors. (R)-Hexbutinol ((R)-9) discriminated $\mathrm{M}_{1}$ and $M_{4}$ from $M_{2}$ receptors, but (S)-9 was $M_{4}$ preferring with a low affinity for $M_{2}$ and $M_{1}$ receptors.

\subsection{Stereoselective interaction with muscarinic receptors}

Four different groups are bound to the central carbon atom (centre of chirality) of the drugs (1-13) studied in this work: a protonated tertiary or a quaternary ammonium group, a hydroxyl moiety, a phenyl or p-fluorophenyl group, and a cyclohexyl group. Formation of an electrostatic interaction (protonated amino/ammonium group) and/or hydrogen bond must be very important for binding: the cationic ammonium group and the hydroxyl group interact strongly with water when the drug is not bound. These interactions are disrupted when the drug reaches its binding site, and must therefore be replaced by strong interaction with the receptor. On the other hand, the phenyl and cyclohexyl groups do not interact favorably with water: dehydration per se is a favorable process. Binding can be further enhanced by close contact (van der Waals) interactions with the receptor, if the asymmetrically substituted carbon atom has the right absolute configuration (Waelbroeck et al., 1990b, 1991b).

We have previously analyzed the binding properties of the enantiomers of procyclidine (3) and hexahydrodifenidol (5) and of structurally related achiral diphenyl and dicyclohexyl analogues (Waelbroeck et al., 1990b, 1991b). Our results support the hypothesis that procyclidine and hexahydro-difenidol recognize four subsites of the muscarinic receptor, their stereoselectivity reflecting the stronger interaction of (R)-procyclidine $((R)-3)$ or $(R)$-hexahydro-difenidol ( $(R)-5)$ and weaker interaction of (S)-3 or (S)-5 with the two hydrophobic subsites.

Assuming that all the compounds studied here have the same binding pattern as procyclidine (3) and assuming that the ammonium groups of the two enantiomers form the same type of ionic bond, we expected 
the following results: (a) pairs of enantiomers differing only in the structure of their amino (ammoniunt) groups should have the same cudismic index, at a certain receptor subtype; (b) the phenyl group of the (R)- and (S)-enantiomers recognize, respectively, a phenyl-preferring and a cyclohexyl-preferring subsitc (Waelbroeck ct al., 1990b, 1991b). p-Fluoro substitution might therefore affect differently the affinity of the two enantiomers and, as a result, change the eudismic index of the compounds. All p-fluoro derivatives, as a group, should however have the same cudismic index at a particular subtype.

Some of our experimental results were in good agreement with these predictions. There was little if any variation of the cudismic index of muscarinic $M_{1}$. $M_{3}$ and $M_{4}$ receptors, for 'procyclidine-like derivatives' (compounds 1-8, table 2). However, differences in cudismic indexes for compounds $1-8$ were observed at $M_{2}$ receptors (tables 1 and 2). This supported the hypotinesis that the ionic bond between the anionic subsite of the receptor and the cationic head of the enantiomers of the muscarinic antagonists $(1-8)$ is independent of the drugs' absolute configuration, at least at $M_{1}, M_{3}$ and $M_{4}$ receptors. $p$-Fluoro substitution affected markedly the cudismic index of hexbutinol (9) and of hexbutinol methindide (10): the phenyl rings seemed to recognize a different region of the receptor, depending on the absolute configuration of the drug, and this was little affected by $\mathrm{N}$-methylation.

On the other hand: (a) N-mcthylation of hexahydro-difenidol $(5 \rightarrow 6)$ and of p-fluoro-hexahydrodifenidol $(7 \rightarrow 8)$ increased the affinity of the $(R)$ - but not of the (S)-enantiomers for cardiac $M$, receptors; (b) the eudismic indexes of hexbutinol (9), hexbutinol methiodide (10) and oxyphencyclimine (13) were significantly lower than the eudismic indexes of the compounds 1-8 at $M_{1}$ and $M_{4}$ receptors; (c) p-fluoro substitution of hexahydro-difenidol (5), hexahydrodifenidol methiodide (6), hexbutinol (9) and hexbutinol methiodide (10) did not similarly affect the binding properties of the four (R)- and (S)-enantiomers.

To account for these discrepancies, we would like to suggest that the position and conformation of each compound within the receptor can be adjusted to achieve añ optimal overall free energy change. When comparing the enantiomers of procyclidine (3) and tricyclamol (4), or trihexyphenidyl (1) and its methiodide 2, for example, this is not a problem: these compounds are quite similar in size and flexibility and probably recognize the same region in the muscarinic binding site. In contrast, the enantiomers of hexahydro-difenidol (5), hexbutinol (9), their methiodides 6 and 10 and oxyphencyclimine (13) are greater in size and/or more rigid molecules: once the ionic bond between the amino (ammonium) group and the anionic subsite of the receptor is formed the chiral centers of
(R)- and (S)-5, 6, 9, 10 and 13 might be unable to reach the same position as (R)- and (S)-procyclidine, respectivcly. If. as a result. the two hydrophobic cycles of $1-13$ come in contact with different regions of a large hydrophobic surfacc in the muscarinic binding site, we would expect: (a) different eudismic indexes; and (b) different effects of p-fluoro substitution on the binding properties of the 'procyclidine-like' drugs $(1-8)$ and 'hexbutinol-like' drugs (9-13).

\subsection{Application of Pfeiffer's rule and of its corollany}

It is often suggested (Lchmann, 1986) that the eudismic index increases linearly with eutomer potency, not only when comparing a series of related drugs interacting with a single receptor (this is known as 'Pfeiffer's rule') but also when comparing the interaction of a single pair of enantiomers with several different receptors or receptor subtypes. As explained by Barlow (1990), it is plausible that the 'iigher the affinity of the cutomer of a chiral compotind, the more it matters how groups are arranged about the centre of chirality. This explains that, as a rule, the cudismic index associated with chiral drugs having a high affinity for the cutomer is larger. Finding a linear correiation between eutomer affinity and eudismic index is, however, far less likely; flexible molecules might have greater affinitics and lower cudismic indexes than more rigid molecules, simply because both enantiomers are capable of adapting their conformations to achieve a better fit with the receptors. We expected that finding a linear correlation between cudismic index and affinity for a set of molccules would give valuable information about the drug-binding nrocess. In ordir to test this hypothesis, we represented our data in figs. 2 and 3 and attempted to find a correlation between eudismic index and eutomer affinity, either for all compounds or for separate sets of the drugs. We found good corrclations when grouping compounds $1 \rightarrow 8$ and compounds (2) $4,9 \rightarrow 13$ in $M_{1}, M_{2}$ and $M_{4}$ receptors (table 3 ).

Most of the compounds in the first group differ in their anmonium (protonated amino) group. The 'eudismic affinity quotient' (slope of the regression line) was small: the affinities of the (R)- and of the (S)-enantiomers varied in parallel. This is in good agreement with our hypothesis that the ionic bond is essential for binding of both enantiomers. Two p-fluoro derivatives 7 and 8 also fell in this group. As discussed above, we believe that. in order to allow the hydrogen bindings of the $\mathrm{OH}$ group and the ionic interactions of the ammonium moieties, the phenyl group of (R)-hexahydro-difenidol ((R)-5) and (S)-5 recognize different regions of the receptor, and that, by chance, p-fluoro substitution induced the same affinity loss at both subsites. 
The second group included hexbutinol (9) derivatives and oxyphencyclimine (13), as well as tricyclamol iodide (4) and (in $M_{1}$ receptors) trihexyphenidyl methiodide (2). The eudismic index of these drugs increased markedly with cutomer affinity.

We were not surpriscd to find in the sccond group hexbutinol (9) and its methiodide (10) and the p-fluorosubstituted derivatives 11 and 12. Indeed, if the phenyl rings of the ( $R$ )- and (S)-configurated drugs recognize different sites in the muscarinic receptor, p-fluoro substitution may affect differently the binding properties of each enantiomer, and change the eudismic index (table 2). On the other hand, we did not expect to find in the same group exyphencyclimine (13), trihexyphenidyl methiodide (2) and tricyclamol iodide (4) which differ from hexbutinol (9) by their ammonium (protonated amino) group.

We would like to suggest that the protonated amino group of the enantiomers of hexbutinol (9) and oxyphencyclimine (13) forms ionic bonds with an aspartate residuc of the receptor. Due to steric hindrance, the positions of the asymmetrically substitutcd carbon atoms of, for example, the hexbutinol or oxyphencyclimine enantiomers are, thus, not identical with those of the tricyclamol enantiomers.

In conclusion: using pure enantiomers rather than racenic mixtures can be helpful for receptor classification (the eudismic indexes may serve as an additional criterium for receptor subtype identification, and the binding pattern of the two enantiomers is sometimes very different). Correlations between the eudismic index and high-affinity enantiomer potency, when present, should however be interpreted only with the greatest çaution.

\section{Acknowledgements}

This work was supported by the Fund for Medical Scientific Research of Belgium (Grant 3.4525.91: J.C. and M.W.). by the Deutsche Forschungsgemeinschaft (R.T.), hy the Volkswagen-Stiflung (R.T.) and hy the Fonds der Che mischen Industrie (G.L.. E.M.. and R.T.).

\section{References}

Barlow, R., 1990. Enantioners: how vitlid is Preiffer's rule?. Trends Pharmacol. Sci. 11. $14 \%$.

Barlow, R.B., K.J. Berry, P.A.M. Glenton, N.M. Nikolaou and K.S. Soh. 197h, A comparison of affinity constants for muscarine-sensitive acetylcholine receptors in guinea-pig atrial pacemaker cells at $29{ }^{\circ} \mathrm{C}$ and in ileum at $29^{\circ} \mathrm{C}$ and $37^{\circ} \mathrm{C}$. Br. J. Pharmacol. 58,613 .

Bonner. T.I. 1989. The molecular hasis of muscarinic receptor diversity. Trends Neurosci. 12, 148.

Cheng. Y. and W.H. Prusoff. 1973, Relationship between the inliblition constant $\left(\mathrm{K}_{\mathrm{i}}\right)$ and the concentration of inhibitor which caluses a 50 percent inhibition $\left(1_{511}\right)$ of an enzymatic reaction. Biochen Pharmacol. 22, 3099.

Dïrje. F.. T. Friche. R. Tacke. E. Mutschler and (3. Lambrech 1990. Nowel pharmacolegical profile of muscarinic receptors me. diating contratetion of the guineat-pig uterus. Naunyn-Schmied. Arch. Pharmacol. 342. $2 \times 4$.

Dïrje, F.. J. Wess. G. Limbrecht. R. Tacke. IE. Mutschler and M.R, Brann. 1991. Antagonist binding profiles of five cloned human muscarinic receptor subtypes. J. Pharmacol. Exp. Ther. 256. 727

Eltzc, M. and V. Figala. 1988. Affinity and selectivity of hiperiden enantiomers for muscarinic receptor subtypes, Eur. J. Pharmacol. $15 \times, 11$.

Eveleigh. P.. E.C. Hulme. C. Schudt and N.J.M. Birdsall. 1989, The existence of stable enantiomers of telenzepine and their sterenselective interaction with muscarinic receptor suhtypes. Mol. Phar. macol. 35. 477 .

Feifel, R., M. Wagner-Rïder. C. Strohmann, R. Tackt, M. Waelbreeck. J. Christophe. E. Mutschler and G. Lambrecht. 1990), Stereoselective inhibition of inuscarinic receptor subtypes hy the enantiomers of hexalhydro-difenidol and acetylenic analogues, $\mathrm{Br}$. J. Pharmacol. 99. 455.

Feifel. R., J.F. Rodrigues de Miranda. C. Strohmann, R. Tacke, A.J. Aasen. E. Mutschler and G. Lambrecht. 1991, Selective labelling of muscarinic $M_{1}$ receptors in calf superior cervical ganglia by ['H] \pm )-lelenzenine, Eur. J. Pharmacol. 195, 115.

Giachetti. A., R. Micheletti and E. Montagna, 1986. Cardioselective profile of AF-DX 116. a muscarine $M 2$ receptor antagonist. Life Sci. 38. 1663.

Gilani. A.S.H. and L.B. Cobbin. 1986. Cardioselectivity of himbacinc: a muscarinic receptor antagonist. Naunyn-Schmied. $\wedge$ rch. Pharmacol. 3.12, it.

Gualtieri. F.. M.N. Romanelli and E. Teodori. 1990, Eudismic analysis of a series of muscarinic agands carrying a 1.3.-oxathiolane ruscleus, Chirality 2.79.

Hanmer, ik.. C.P. Berric, N.J.M. Birdsall, A.S.V. Burgen and E.C. Hulnc. 1980. Pirenzepine distinguishes between different sub. classes of muscurinic receptors, Nature 28.3. $\%$.

Lambrecht. G. and E. Mutschler. 1986. Chirality as a tool for suhclassification of receptors, in: Innovative Approaches in Drug Research, ed. A. F. Harms (Elsevier. Amsterdam) p. 353.

Launbrecht, G.. R. Feifel, U. Moser. A.J. Ausen, M. Waelbrocek, J. Christople and E. Mutschler, 1988, Stereoselectivity of the enantiomers of trilexyphenidyl and its methiodide at muscarinic receptor subtypes, Eur. J. Pharmacol. 155. 167.

Lambreclit. G.. R. Feifel. M. Wagner-Röder. C. Strolimann, II. Zilch, R. Tacke, M. Waelhroeck. J. Christophe, II. Boddeke and [:. Mutschler, 1989, Affinity profiles of hexabyclro-sila-difenido] analogues at muscarinic receptor subtypes, Eur. J. Plarmacol. 168.71.

Lazareno, S. and F.F. Roberts, 198?. Functional and hinding studies with muscarinic $M_{2}$-suhtype se'iective antagonists. Br. J. Pharmacol. 98.309 .

Lazareno, S., N.J. Buckley and F.F. Roherts. 1990. Characterization of muscarinic $M_{4}$ hindling sites in rabhit lung, ehicken heart. and NGiok-15 cells, Mol, Phatmacol. 38, 8115 .

Lelımann, F.P.A.. 1986, Stereoisomerism and drug action. Trends Pharmacul. Sci. 7. 281

Levine, R.R. and N.J.M. Birdsall (cds.), 1989. Suhtypes of muscarinic recepters IV. Trends Pharmacol. Sci. I) (Suppl.).

Lonry, O.H. N.J. Rosebrough. A.L. Farr and R.J. Randall, 1951. Protcin measurenent with the Folir phenol reagent. J. Biol. Chem. 193. 265 .

Melchionre, C.. P. Angeli, (;. Limblorecht. E. Mutschler, M.T. Piechio and J. Wess. 1987. Antimuscarinic action of methoctraminc, a new cardioselective $M_{2}$ muscarinic receptor antagonist. atone and in conbination with atropine and gallamine, Eur. J. Pharmatcol. 144. 117 
Michel. A.D., R. Delmendo, E. Stefanich and R.L. Whiting. 1989. Binding characteristics of the muscarinic receptor subtype of the NGI08-15 cell line. Naunyn-Schmied. Arch. Pharmacol. 341). 62.

Mutschler, E. and G. Lambrecht, 1984. Selective muscarinic agonists and antagonists in functional tests. Trends Pharmacol. Sci. 5 (Suppl.). 39.

Richatdson, A. and A. Humrich. 1984. A microcomputic program for the analysis of radioligand hinding cances and other dosc-re. sponse dati, Trends Pharmacol. Sci. 5, 47.

Schjelderup, L., O. Harbitz. P. Groth and A.J. Aasen. 1987. Synthese of (S)-(+)-trihexyphenidyl hydrochloride and (SH + +)-procyclidine hydrachloride. two anticholinergics, using (S)-( - 1.3-cyclolex yl-3-hydroxy-3-phenyl/topanoic acid as chiral synthon. Acti Chem. Scand. B41, 356.

Schjelderup, L.. M.R. Kozlouski. A. Weissman and A.J. Aasen. 1988. Antimuscarinic effects of (R). and (S)-oxyphencyclimine hydrochloride, Pharm. Res. 5, 236.

Strohmann, C. S. Baverecker, H.K. Canumenes, P.G. Jones, E. Mutschler. G. Lambrecht and R. Tacke. 1491. Enantiomers of the muscarinic antagonist 1-cyclolexyl-1-(4-fluorophenyl)-4piperidino-1-butanol (p-fluoro-hexihydro-difenidoi): synthesis. absolute configuration and enantiomeric purity. Liebigs Ann. Chem. 523.

Tacke, R., H. Linoh. D. Schomhurg. L. Ernst, U. Moser, E. Mutschler and G. Lumbrecht. 19st. On the absolute configuration of the enantiomers of the antinuscarinic as. nts prescyclidine and tricy. clamol indide: X-ray structural analysis of (R)-1-[3-cyclohexyl-3hydroxy-3-phenylpropul]-1-methylpyrrolidinium iodide. Liebigs Ann. Chem. 242.

Tacke. R.. C. Sirohmann. S. Sarge, H.K. Cammenga, D. Schomburg. E. Mutschler and 6 . Lambrecht, 1989. Preparation and properties of the enantiomers of the selective antimuscarinic agent 1-cyclohexyl-1-phenyl-4-piperidino-1-butanol (hexahydro-difenidol). Liehigs Ann. Cheno. 137.

Waclbrocec, M. M. Tastenoy, J. Camus and J. Christophe, 1990a, Binding of scicctive antagnnists to four muscarinic receptors $\left(M_{1}\right.$ 10 $\mathrm{M}_{4}$ ) in rat forebrain. Mol. Pharmacol. 38, 267.

Watetbroeck. M.. J. Camus, M. Tastentoy, G. Lambrecht. E. Mutschler, R. Tacke and J. Christophe. 1990b. Stertoselectivity of procyclidine binding to muscarinic receptor subtypes $M_{1}, M_{2}$ and $M_{4}$, Eur. J. Pharmacol. Mol. Pharmacol. 189, 135.

Wiclbroeck. M., J. Camus, M. Tastenoy, G. Lambrecht, E. Mutschler, C. Strohmann, R. Tacke and J. Christophe. 1991 a. Binding affinilies of hexahydro-difenidol and hexahydro-sila-difenidol analogues at four muscarinic receptor subtypes: constitutional and stereschemicai aspects. Eur. J. Pharmacol. Mol. Pharmacol. 206. 95 .

Wathroeck. M., J. Camus, M. Tistenoy, E. Mutschler. C. Strohmann, R. Tacke, G. Lambrecht and J. Christophe, 199/h, Stcreosclectivity of (R)- and (S)-hexahydro-difenidol binding to neuroblastoma $M_{1}$, cardiac $M_{2}$. pancreatic $M_{3}$ and striatum $M_{4}$ muscarinic receptors. Chirality $3,118$. 